\title{
Measurement and Management on the Risk of Internet Finance
}

\author{
Xin Gao \\ Northeast Dianli University \\ Jilin, China, 132012
}

\begin{abstract}
At present, the Internet financial, as the product of the combining traditional financial industry and Internet, is developing rapidly. Compared with traditional financial, Internet finance speed up the development of China's financial system for it can make up for the shortage of traditional financial and carry on innovation on the basis of this. But the risk on the Internet financial system is extremely complex and dangerous; strengthening preventive measures on it is an urgent affair. This article will put the Internet financial as a systematic format to evaluate the risk on it. In order to achieve this goal, we will make an empirical analysis that combined analytic hierarchy process and fuzzy mathematics. We will make a fuzzy comprehensive evaluation based on division of Internet financial risk hierarchy. The results show that the current China's Internet financial system is in a state of high risk. Some kind of risk, such as credit risk and financial business risk, become the key factors to actuate the system risk.
\end{abstract}

Keywords-internet finance; risk measurement; risk management

\section{INTRODUCTION}

In 2002, Alibaba launched the first internet credit product, Ali small loan. And from 2007 to 2010, Alibaba cooperated with the CCB, ICBC and launched the Internet credit products respectively. In 2013, Alibaba cooperated with Tianhong fund launched $\mathrm{Yu}$ Ebao as the first internet banking product, followed by a number of Internet companies have set foot in the field of Internet banking, such as financial links, Baidu "hundred", Suning easy pay treasure "etc. Many banks also launched innovative monetary fund's relying on its online banking channels, resource advantage, for they influenced by the fund companies. Under this kind of background, many internet financial products, such as the taxi software, Jingdong IOUs, P2P network lending, were sprang up like mushrooms. Accompanying with the rapid development of the internet financial, however, risks such as the absence of supervision, credit default, maturity mismatch, legal synthetic regulation, monetary policy, credit information abuse, asymmetric information, technology and information security, are highlighted.

\section{INTERNET FINANCIAL RISK}

Internet finance is a new form of financial which relies on to Internet tools such as pay, cloud computing, social networks and search engines, to achieve the financial business including financing, payment and information intermediaries. Compared with the traditional finance, Internet finance is more transparency, participation degree is higher, and the operation is more rapid, intermediate costs are lower, expand the scope of the financial sector. What's more, it enriches the field of financial business and promotes the development speed of the financial industry rapidly.

Internet banking business involves multiple participants such as financial service providers, consumer and commercial banks. They all carry on a variety of financial business and affect each other. The relations between them are complex. The main difference and its current situation, business links and possible future development direction will affect the results of risk assessment.

As a product of the comprehensive combination of Internet technology and financial, Internet finance expanded the range of financial business, reduce the financial cost, improve the financial business processing speed, but financial risk also can not be ignored. In order to study further, we'll analyze the Internet financial risk from the following five aspects.

Firstly, the risk of information technology and reputation, including information security risk, technology risk and reputation risk. Different from the traditional commercial banks that have a strong independent core business system, the internet financial business moved in an opening network communication system. So in the process of balancing the technical maintenance investment and operation cost tradeoff, the internet finance companies must facing the risk of information security and technology. At the same time, the integrity and operating condition of the enterprise also has a great influence on the security of customer information in a certain extent.

Secondly, the business risk of internet finance, including information asymmetry risk, market risk and liquidity risk. Because of the existence of information asymmetry, internet financial business may faced market selection risk and the internet financial market may like a lemon market. What' a lemon market? It means that products with low price or low quality are easer accepted at the early stage of Internet finance. This kind of undesirable phenomenon is not conducive to the sound progress of the Internet financial market, easy to bring the Internet financial market risk. 
Thirdly, the risk of policy and law. Although there are a series of law about the internet finance have already been legislated, the legal system is not perfect. Internet financial legislation in our country is relatively backward and fuzzy, lagging of relevant regulations, namely regulatory gaps. As aresult of it, some bad people take advantage of loopholes of law and carry out informal financial activities that bring the Internet financial risks. So, perfect the relevant laws and regulations constantly is the key to reduce Internet financial legal risk.

Fourthly, credit risk, including credit risk, internal fraud risk, external risk of fraud, abuse of credit information risk. Different from traditional commercial banking, Internet banking industry do not have an open information repositories, the enterprises closed to each other are separated. And there is still not a link with the people's Bank of China's credit system, nor with the third-party credit agency. Management system, operating procedures, risk control system are still not be construct perfectly in not a few of internet financial enterprises. The domestic Internet credit business has not been under a comprehensive and effective regulation. The consumer protection mechanism is not perfect. Vicious incident such as internal employee fraud, external market fraud and credit information abuse flares at times.

Fifthly, operating risk. Operation miss of Internet transaction subject in the process of operation may be a reason that lead business risks. Security of Internet operation is crucial for there has a great relevance between it and the authorization to use the internet account, the internet banking risk management system, the communication of the participants. Because of the Internet banking business is conducted in the virtual environment. It may lead risk if the transaction subjects of it make error in operation.

\section{EMPIRICAL TEST}

Scholars at home and abroad have conducted the research on the Internet finance from different angles. For example, Smedlund A (2012) pointed out that the credit risk is widespread, even in the countries with sound legal. He has also analyzed the importance of credit in the financial deeply. Meng Zan and Li Mingxuan (2014) analyzed our country's financial market data from an empirical point of view, and drew the conclusion that since the Internet banking came into being in our country the credit risk of financial institutions changed structurally, and the credit risk was due to the emergence of Internet banking increased. Based on the analysis of existing, this paper attempts to using the fuzzy hierarchy analysis method that combined with the analytic hierarchy process and fuzzy mathematical theory to decompose all kinds of risk factors of Internet banking, then seek out the importance of the factors according to the evaluation index hierarchy. Eventually, collate them according to the importance and draw the conclusion.

Our test will be divided into four steps as follows.

- The first step is to determine the risk weights. The key of it is the construction of a hierarchical structure, including the target layer, criterion layer and index layer. Our model will select 5 indicators including the five aspects of the Internet financial risks discussed above. The 5 indicators will be subdivided into 15 secondary indexes.

- The second step is to construct a fuzzy judgment matrix and to sort in single level and conduct consistency check. In this step we'll judge the importance of all the indicators by AHP method. The weights of the five first grade indexes are showed in "Table. I".

TABLE I

\begin{tabular}{|l|l|}
\hline \multicolumn{1}{|c|}{ indicator } & percent \\
\hline Information technology and reputation risk & 0.157 \\
\hline Business risk & 0.173 \\
\hline Policy and law risk & 0.089 \\
\hline Credit risk & 0.475 \\
\hline Operating risk & 0.096 \\
\hline
\end{tabular}

- Then we'll calculate the weights of all the 15 secondary indexes by multiple comparisons. The results showed in "Table. II".

TABLE II.

\begin{tabular}{|l|l|l|}
\hline \multirow{2}{*}{ First grade index } & secondary index & weight \\
\hline \multirow{3}{*}{ Information technology and reputation risk } & & $\mathrm{A} 11$ \\
\cline { 2 - 3 } & $\mathrm{A} 12$ & 0.598 \\
\cline { 2 - 3 } & $\mathrm{A} 13$ & 0.263 \\
\hline \multirow{3}{*}{ Business risk } & $\mathrm{A} 21$ & 0.139 \\
\cline { 2 - 3 } & $\mathrm{A} 22$ & 0.607 \\
\cline { 2 - 3 } & $\mathrm{A} 23$ & 0.238 \\
\hline \multirow{3}{*}{ Policy and law risk } & $\mathrm{A} 31$ & 0.155 \\
\cline { 2 - 3 } & $\mathrm{A} 32$ & 0.067 \\
\cline { 2 - 3 } & $\mathrm{A} 33$ & 0.647 \\
\hline \multirow{3}{*}{ Credit risk } & $\mathrm{A} 41$ & 0.286 \\
\cline { 2 - 3 } & $\mathrm{A} 42$ & 0.143 \\
\cline { 2 - 3 } & $\mathrm{A} 43$ & 0.533 \\
\hline \multirow{3}{*}{ Operating risk } & $\mathrm{A} 51$ & 0.124 \\
\cline { 2 - 3 } & $\mathrm{A} 52$ & 0.648 \\
\cline { 2 - 3 } & $\mathrm{A} 53$ & 0.228 \\
\hline
\end{tabular}

- The last step is to analyze the fuzzy comprehensive evaluation model and operation results. Assuming that $\mathrm{Y}=\{\mathrm{y} 1, \mathrm{y} 2, \mathrm{y} 3, \mathrm{y} 4, \mathrm{y} 5\}$ is a risk fuzzy evaluation set. The meaning of the five elements are very high, higher, general, low and very low.

We invited 15 financial professionals and 15 Internet practitioners to score all the indicators. Then score results based on the fuzzy comprehensive evaluation formulas $\mathrm{Wi}=$ $\mathrm{Bi} * \mathrm{Ri}$, the evaluation results of each secondary index can be obtained as follows:

$\mathrm{W} 1=(0.60635,0.28735,0.04928,0.04632,0.0107)$

$\mathrm{W} 2=(0.62713,0.2468,0.06835,0.0363,0.02142)$ 
$\mathrm{W} 3=(0.50315,0.25145,0.15068,0.07973,0.01499)$

$\mathrm{W} 4=(0.29798,0.2816,0.25032,0.10132,0.066878)$

$\mathrm{W} 5=(0.037655,0.09018,0.2216,0.50745,0.14312)$

Then we used the fuzzy comprehensive evaluation equation $\mathrm{A}=\mathrm{B} * \mathrm{~W}$ to calculate the evaluation results of the primary indexes:

$$
A=(0.0891,0.2719,0.1596,0.4295,0.0502)
$$

According to the maximum membership degree principle, the maximum value is 0.4295 , the corresponding risk rating is "high".

According to the above research that there is still high risk in the process of Internet banking development. The credit risk occupies the maximum weight in the five indicators that we selected, the second is the financial business risk. So they must be paid more attention. This not means we needn't pay attention to the other kinds of risks although they are reducing.

\section{CONSTRUCT AN INTERNET FINANCIAL RISK MANAGEMENT SYSTEM}

\section{A. Construct an Internet Financial Security System}

The safety of the operation of Internet banking services can be improved by building a sane internet financial security system. In order to build a security system, we can start with two aspects as follows. On the one hand, we should improve the operating environment of the internet finance. We should strengthen the construction of the computer firewall system, enhance the security of the computer system. This is the basis of the internet financial business can effectively implement. On the other hand, we should strengthen the management of the data. In order that the data of internet financial business can't be theft, destructed or lost, we should make uniform, reasonable and effective technical standards and norms. In accordance with this standard specification to choose appropriate Internet financial technology, design the formulation of reasonable application of technology solutions, use Internet banking technology scientifically, strengthen the implementation of Internet finance safety, validity and rationality, reduce the financial risk of Internet technology.

\section{B. Improve the Risk Management System of Internet Banking}

We must construct an effective risk management system, draw up a scientific and reasonable development planning, to improve safety and effectiveness of the implementation of Internet banking financial business. Of course, the key that ensure the effective application of Internet banking is to build a sound internet financial business risk management system. There are two things need noticed when establish an Internet banking business risk management system: one is to strengthen internal control of the financial institutions, the other is to speed up the construction of the social credit system.

\section{REFERENCES}

[1] Liansheng Zheng, "China's Internet Banking: model, impact, nature and risk” International Economic Review, pp103-118, Sep. 2014

[2] Jianguang Zeng. "Network Security Risk Perception and Asset Pricing of Internet Finance" Economic Research Journal pp131-145, July 2015. 